\title{
Amylin Analogues in the Treatment of Diabetes Mellitus: Medicinal Chemistry and Structural Basis of its Function
}

\author{
Ernest Adeghate*,1 and Huba Kalász ${ }^{2}$ \\ ${ }^{I}$ Department of Anatomy, Faculty of Medicine \& Health Sciences, United Arab Emirates University, Al Ain, United Arab \\ Emirates; ${ }^{2}$ Department of Pharmacology and Therapeutics, Semmelweis University, Budapest, Hungary
}

\begin{abstract}
Amylin, (islet amyloid polypeptide) or diabetes-associated peptide is co-secreted with insulin in the islet of Langerhans of diabetic patients in approximately 1:100, amylin-insulin ratio. The soluble form of amylin, an analogue of amylin, is used as a supplement to insulin in the treatment of type 1 diabetes. Co-administration of amylin analogue with insulin to patients with type 1 diabetes induced a larger reduction in proprandial hyperglycemia, with a concomitant reduction in the level of glucagon when compared to insulin monotherapy. The actions of amylin analogues appear to be synergistic to insulin, with which it is co-released from insulin-producing beta cells after a meal. Amylin analogues such as pramlintide has been shown to significantly reduce body weight, HbA1c values and even the dosage of insulin. A moderate weight loss can also be achieved in obese patients with or without diabetes. A major side effect of some amylin analogues includes nausea and excitation of the area postrema. This review examines the medicinal chemistry of amylin and its analogues and their effects.
\end{abstract}

Keywords: Amylin, type 1 diabetes, medicinal chemistry, pramlintide.

\section{INTRODUCTION}

Diabetes mellitus continues to pose a significant burden on healthcare services worldwide because of its high prevalence. Different management protocols, including diet modification, lifestyle changes, therapeutic regimens have been developed to reduce the signs and symptoms, and hence the severity of diabetes mellitus. Attention has been focused on several bioactive agents that are capable of increasing insulin release especially in type 1 diabetes. One of such agents is amylin. Amylin, also called IAPP (islet amyloid polypeptide) or diabetes-associated peptide, is produced by pancreatic beta cell and co-secreted with insulin. It occurs in the islet of Langerhans of diabetic patients in approximately 1:100 amylin- insulin ratio. It has long been reported that amylin, like amylin beta, known to be associated with Alzheimer's disease, can induce apoptosis in pancreatic beta cell $[1,2]$. Amylin was discovered in human in 1987 by Cooper et al [3] and in cats by Westermark et al. [4]

\section{STRUCTURE OF AMYLIN}

Amylin is an insoluble protein with a relatively low tissue concentration. Amylin forms long stable fibres which are arranged in regular pattern [5]. It is a small peptide with a molecular weight of only $3.9 \mathrm{kDa}[1,2]$. Its amino acid sequence is $46 \%$ identical to that of human beta-CGRP (calcitonin-gene related peptide). The ability of amylin to destroy

*Address correspondence to this author at the Department of Anatomy, Faculty of Medicine and Health Sciences, United Arab Emirates University, Al-Ain, United Arab Emirates; Fax: +971-3-7672033;

E-mail: eadeghate@uaeu.ac.ae pancreatic beta cell appears to be species specific. For example rat and mice amylin have 3 proline substitutions at amino acid positions 25,28 and 29 . These substitutions have been reported to prevent the development of the fibrillary form of amyloid. The inability of this type of amylin to destroy pancreatic beta cells have been used to development a human amylin analogue capable of stimulating insulin release.

\section{MEDICINAL CHEMISTRY OF AMYLIN}

Human amylin has a disulfide bond between cysteine residues 2 and 7 . The amidated C-terminal and the disulfide bond must be intact in order for amylin or its analogues to be biologically active [6]. The amino acid sequences of amylin and its analogue (pramlintide) are shown in (Figs. 1, 2).

Since amylin is highly insoluble, and even toxic to pancreatic beta cells because of deposition of fibrillary proteins, an aqueous, non-aggregating form of amylin was established by replacing three amino acid residues. This form of amylin was found to be effective in reducing blood glucose level when given subcutaneously [7].

Pramlintide acetate, a soluble amylin analogue, marketed as Symlin ${ }^{B}$, is used as a supplement to insulin in the treatment of type 1 diabetes. For example, co-administration of amylin analogue with insulin to a small cohort of adolescent with type 1 diabetes induced a larger reduction in proprandial hyperglycemia, with a concomitant reduction in the level of glucagon when compared to insulin monotherapy $[8$, 9]. The actions of amylin and its analogues appear to be synergistic to insulin, with which it is co-released from insulin-producing beta cells after a meal. The positive effect of 


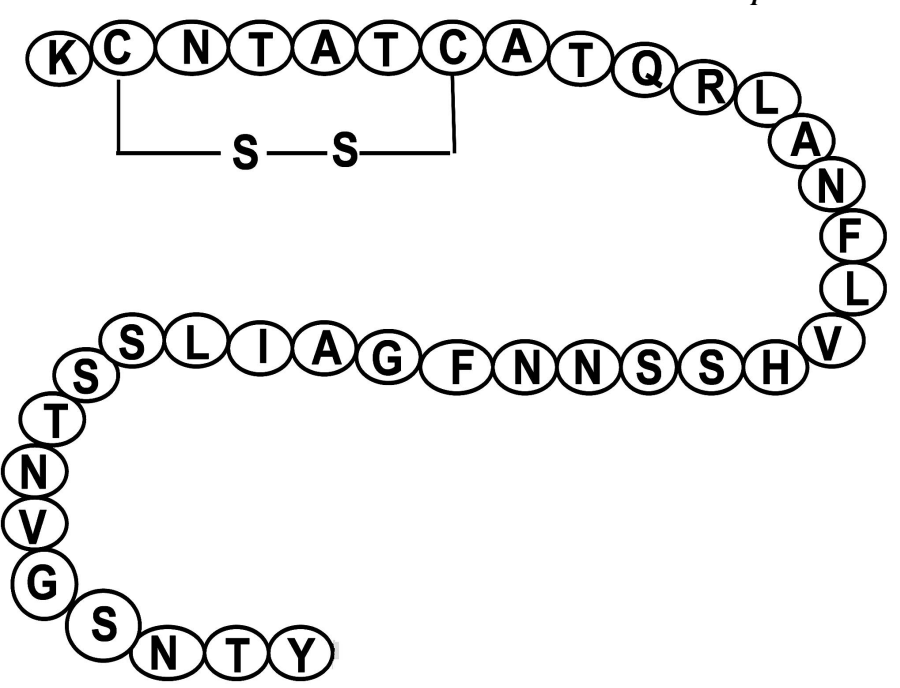

Fig. (1). Shows the amino acid sequence of amylin with cystine bond at position 2 and 7. The disulfide bond must be intact in order for amylin to be biologically active.

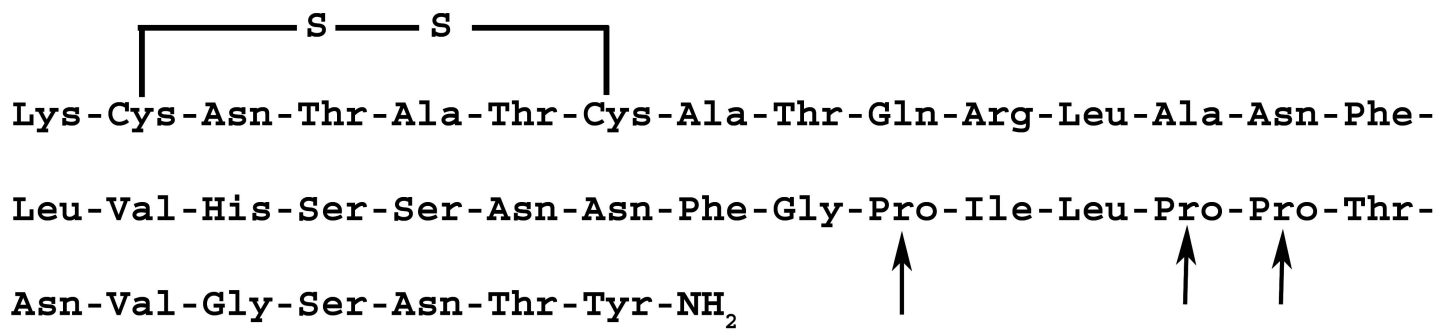

Fig. (2). Amino acid sequence of the amylin analogue, pramlintide: Note the cystine bond at 2 and 7 positions. The disulfide bond must be intact in order for amylin analogues to be biologically active. The amino acids at positions 25, 28 and 29 have been replaced by proline (arrows).

pramlintide in the treatment of diabetes was acknowledged by an FDA (Food and Drug Administration) approval in March 2005

Pramlintide, given subcutaneously at a dose of $30 \mu \mathrm{g}$ per meal, significantly reduced body weight, HbA1c values and even the dosage of insulin [10].

A moderate body weight loss can also be achieved in obese patients with or without diabetes [11]. A major side effect of pramlintide is nausea [12] and vomiting due to a possible excitation of the area postrema [13] in the medulla oblongata

\section{BIOLOGICAL ACTIONS OF NATIVE AMYLIN AND AMYLIN ANALOGUES}

\section{Native Amylin}

Native human amylin can form fibrils in vitro and has the ability to induce apoptosis in cultured pancreatic beta cells [6]. However, some reports have shown that even the nonfibril form of human amylin (1-19 residues of human amylin) is noxious to the beta cells of the pancreas. This non-fibrillary fragment is capable of membrane destruction at low concentrations $[5,14]$. The ability of amylin to destroy membranes has been shown by several methods including NMR spectroscopy. Amylin is related to calcitonin and calcitonin-gene related peptide, messenger proteins which play a role in the regulation of several metabolic functions [15].

\section{Effects of Amylin Analogue}

Amylin analogues such as pramlintide function together with insulin in the control of blood glucose levels. It also slows rapid emptying of the stomach [16].

\section{Gastrointestinal Tract}

Amylin analogues have been shown to reduce food intake by slowing of gastric emptying. Other studies also showed that it reduces the release of several digestive enzymes and bile acid. These properties play a role in the ability of amylin to delay the appearance of nutrients in the circulation [15], and eventually, maintain glycemic control.

In addition, amylin analogues inhibit the production of glucagon, which is involved in the regulation of gluconeogenesis [17]. Reduction in glucagon secretion results in lower hepatic glucose production [18] from the liver. This effect may contribute to the reduction in the insulin dosage required to maintain euglycemia $[19,20]$.

\section{Skeletal Muscle}

Amylin has been reported to oppose the metabolic actions of insulin in skeletal muscle cells [16]. However, the role of its skeletal muscle action on the maintenance of glycemic control is not clear. 


\section{Food Intake}

Peripherally administered amylin analogue, induced anorectic effect through a direct action on the area postrema and/or nucleus tractus solitarius. Amylin analogue also inhibits ghrelin release, an orexigenic peptide $[18,21]$.

\section{RECEPTORS OF AMYLIN}

More than six types of amylin receptors AMY1(a), AMY2(a), AMY3(a), AMY1(b) AMY2(b) and AMY3(b) have been identified. These receptors have two units, a calcitonin core surrounded by a receptor activity modifying protein [22]. The receptor activity modifying proteins are divided into 3 classes of proteins that traverse the plasma membrane [23].

AMY1 receptor displays a high affinity for salmon calcitonin, amylin and calcitonin-gene-related peptide but a lower affinity for mammalian calcitonin [24]. The affinity of amylin2 and amylin3 receptors for calcitonin and amylin is similar but lower for calcitonin-gene-related peptide.

Amylin binding sites have been localized to several circumventricular organs, such as the subfornical organ, organum vasculosum lateralis terminalis and the area postrema in the medulla oblongata. These areas are outside of the blood brain barrier, indicating that they will respond to the level of pancreatic beta cell derived amylin [25]

\section{METABOLISM OF AMYLIN}

The amylin produced in pancreatic beta cell alongside insulin is eventually excreted by the kidney. Amylin is degraded by insulin-degrading enzyme, a $\mathrm{Zn}^{2+}$-rich metalloprotease, which also takes part in the elimination of insulin [26, 27]. Absence of insulin-degrading enzyme in rodents induces glucose intolerance and cerebral accumulation of amyloid beta, whereas effective insulin-degrading enzyme activity reduces accumulation of amyloid.

\section{CONCLUSION}

Amylin or diabetes-associated peptide, is co-secreted with insulin in the islet of Langerhans of diabetic patients in approximately 1:100 amylin: insulin ratio. The soluble form of amylin (e.g. pramlintide) is used as a supplement to insulin in the treatment of type 1 diabetes. The actions of amylin analogues appear to be synergistic to that of insulin and can significantly reduce body weight, $\mathrm{HbAlc}$ values and even the dosage of insulin.

\section{ACKNOWLEDGEMENTS}

The study was supported by the UAE University

\section{REFERENCES}

[1] Lorenzo, A.; Razzaboni, B.; Weir, G. C.; Yankner, B. A., Pancreatic islet cell toxicity of amylin associated with type-2 diabetes mellitus. Nature, 1994, 368, (6473), 756-60.

[2] Sasahara, K.; Hall, D.; Hamada, D. Effect of lipid type on the binding of lipid vesicles to IAPP amyloid fibrils. Biochemistry, 2010, 49, 3040-3048.

[3] Cooper, G. J.; Willis, A. C.; Clark, A.; Turner, R. C.; Sim, R. B.; Reid, K. B. Purification and characterization of a peptide from amyloid-rich pancreases of type 2 diabetic patients. Proc. Natl. Acad. Sci. USA, 1987, 84, (23), 8628-8632.
[4] Westermark, P.; Wernstedt, C.; Wilander, E.; Hayden, D. W.; O'Brien, T. D.; Johnson, K. H., Amyloid fibrils in human insulinoma and islets of Langerhans of the diabetic cat are derived from a neuropeptide-like protein also present in normal islet cells. Proc. Natl. Acad. Sci. USA, 1987, 84, (11), 3881-3885.

[5] Nanga, R. P.; Brender, J. R.; Xu, J.; Veglia, G.; Ramamoorthy, A., Structures of rat and human islet amyloid polypeptide IAPP(1-19) in micelles by NMR spectroscopy. Biochemistry, 2008, 47, (48), 12689-12697.

[6] Roberts, A. N.; Leighton, B.; Todd, J. A.; Cockburn, D.; Schofield, P. N.; Sutton, R.; Holt, S.; Boyd, Y.; Day, A. J.; Foot, E. A. Molecular and functional characterization of amylin, a peptide associated with type 2 diabetes mellitus. Proc. Natl. Acad. Sci. USA, 1989, 86, (24), 9662-966.

[7] Thompson, R.G.; Peterson, J.; Gottlieb, A.; Mullane, J. Effects of pramlintide, an analog of human amylin, on plasma glucose profiles in patients with IDDM: results of a multicenter trial. Diabetes, 1997, 46, 632- 636 .

[8] Heptulla, R.A.; Rodriguez, L.M.; Mason, K.J.; Haymond, M.W. Twenty-four-hour simultaneous subcutaneous Basal-bolus administration of insulin and amylin in adolescents with type 1 diabetes decreases postprandial hyperglycemia. J. Clin. Endocrinol. Metab., 2009, 94 (5), 1608-1611.

[9] Hassan, K.; Heptulla, R.A. Reducing postprandial hyperglycemia with adjuvant premeal pramlintide and postmeal insulin in children with type 1 diabetes mellitus. Pediatr. Diabetes, 2009, 10 (4), 264268.

[10] Kishiyama, C.M.; Burdick, P.L.; Cobry, E.C.; Gage, V.L.; Messer, L.H.; McFann, K.; Chase, H.P. A pilot trial of pramlintide home usage in adolescents with type 1 diabetes. Pediatrics, 2009, 124, 1344-1347.

[11] Dunican, K.C.; Adams, N.M.; Desilets, A.R. The role of pramlintide for weight loss. Ann. Pharmacother., 2010, 44 (3), 538-545.

[12] Ryan, G.J.; Jobe, L.J.; Martin, R. Pramlintide in the treatment of type 1 and type 2 diabetes mellitus. Clin. Ther., 2005, 27(10), 1500-1512.

[13] Day, C. Amylin analogue as an antidiabetic agent. Br. J. Diabetes Vasc. Dis., 2005, 5,151-154.

[14] Brender, J. R.; Lee, E. L.; Cavitt, M. A.; Gafni, A.; Steel, D. G.; Ramamoorthy, A. Amyloid fiber formation and membrane disruption are separate processes localized in two distinct regions of IAPP, the type-2-diabetes-related peptide. J. Am. Chem. Soc., 2008, 130, (20), 6424-6429.

[15] Pittner, R. A.; Albrandt, K.; Beaumont, K.; Gaeta, L. S.; Koda, J. E.; Moore, C. X.; Rittenhouse, J.; Rink, T. J. Molecular physiology of amylin. J. Cell. Biochem., 1994, 55 Suppl, 19-28.

[16] Cooper, G.J. Amylin compared with calcitonin gene-related peptide: structure, biology, and relevance to metabolic disease. Endocr. Rev., 1994, 15, 163-201.

[17] Young, A. Effects of amylin in liver. Adv. Pharmacol., 2005, 52 229-234

[18] Young, A. Inhibition of food intake by amylin. Adv. Pharmacol., 2005, 52, 79-98

[19] Fineman, M.; Weyer, C.; Maggs, D.G.; Strobel, S.; Kolterman, O.G: The human amylin analog, pramlintide, reduces postprandial hyperglucagonemia in patients with type 2 diabetes mellitus. Horm. Metab. Res., 2002, 34, $504-508$.

[20] Ratner, R. E.; Dickey, R.; Fineman, M.; Maggs, D. G.; Shen, L.; Strobel, S. A.; Weyer, C.; Kolterman, O. G., Amylin replacement with pramlintide as an adjunct to insulin therapy improves longterm glycaemic and weight control in Type 1 diabetes mellitus: a 1year, randomized controlled trial. Diabet. Med., 2004, 21, (11), 1204-1212.

[21] Hollander, P.; Maggs, D.G.; Ruggles, J.A., Fineman, M.; Shen, L.; Kolterman, O.G.; Weyer, C. Effect of pramlintide on weight in overweight and obese insulin-treated type 2 diabetes patients. Obes. Res., 2004, 12, 661-668.

[22] Hay, D. L.; Christopoulos, G.; Christopoulos, A.; Sexton, P. M., Amylin receptors: molecular composition and pharmacology. Biochem. Soc. Trans., 2004, 32, 865-867.

[23] Sexton, P.M.; Albiston, A.; Morfis, M.; Tilakaratne, N. Receptor activity modifying proteins. Cell Signal., 2001, 13, 73-83

[24] Poyner, D.R.; Sexton, P.M.; Marshall, I.; Smith, D.M.; Quirion, R.; Born, W.; Muff, R.; Fischer, J.A.; Foord, S.M. International Union of Pharmacology. XXXII. The mammalian calcitonin gene-related 
peptides, adrenomedullin, amylin, and calcitonin receptors. Pharmacol. Rev., 2002, 54, 233-246.

[25] Young, A. Amylin receptor pharmacology. Adv. Pharmacol., 2005, 52, 47-65.

[26] Bennett, R.G.; Duckworth, W.C.; Hamel, F.G. Degradation of amylin by insulin-degrading enzyme. J. Biol. Chem., 2000, 275, 36621-36625.
[27] Shen, Y.; Joachimiak, A.; Rosner, M.R.; Tang, W.J. Structures of human insulin-degrading enzyme reveal a new substrate recognition mechanism. Nature, 2006, 443, 870-874.

(C) Adeghate and Kalász; Licensee Bentham Open.

This is an open access article licensed under the terms of the Creative Commons Attribution Non-Commercial License (http: //creativecommons.org/licenses/by$\mathrm{nc} / 3.0 /$ ) which permits unrestricted, non-commercial use, distribution and reproduction in any medium, provided the work is properly cited. 